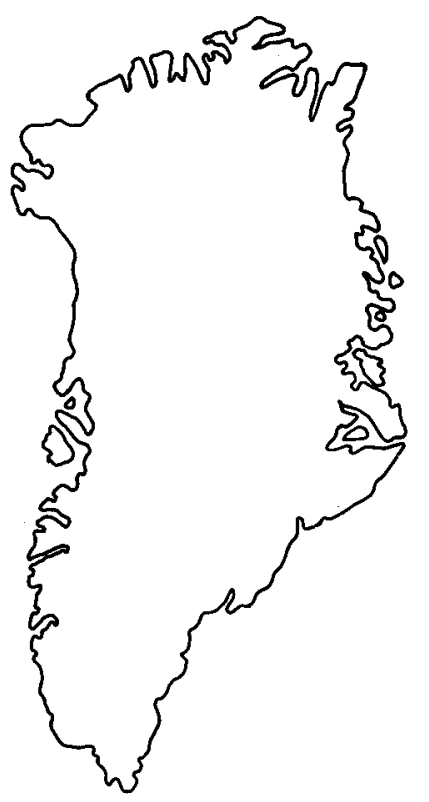

\title{
Notes on the trilobite faunas of the Henson Gletscher Formation (Lower and Middle Cambrian) of central North Greenland
}

\author{
Mark R. Blaker
}

\begin{abstract}
Cambrian trilobite faunas collected from a $90 \mathrm{~m}$ section of the Henson Gletscher Formation in southern Freuchen Land are described. Nineteen species are discussed, six of which are new. Aspects of the ontogenies of two species of Ogygopsis Walcott, 1889 are outlined, and initial correlations of $O g y$ gopsis made with North America and Siberia. The first occurrences outside China of species assigned to Arthricocephalus Bergeron, 1889 and Changaspis Lee, 1963 are reported. Problems of ptychopariid classification for the early Cambrian are covered, and proposals for a new approach to understanding ptychopariid relationships are outlined.
\end{abstract}

M. R. B., Department of Geology, University of Keele, Staffordshire ST5 5BG, U.K.

During regional mapping of the Lower and Middle Cambrian of southern Freuchen Land, central North Greenland, by J. S. Peel and S. C. Wright in 1984, extensive collections of trilobites were made from a well-exposed section of the Henson Gletscher Formation of the Brønlund Fjord Group north of Jungersen Gletscher (figs 1 \& 2). This material, together with further collections made from the same section by Peel, C. Møller-San Pedro and myself in 1985, will form the basis of a part of my Ph.D. thesis (University of Keele, U.K.). This report gives an initial appraisal of these trilobite faunas, as well as outlining some of the directions in which it is anticipated that the study will develop. A generalised stratigraphic section (fig. 3) indicates the relative positions of the trilobite faunas discussed. General descriptions of the Cambrian sequence in this part of North Greenland were given by Ineson \& Peel (1980, in press), Peel (1982) and Peel \& Wright (1985).

\section{Fauna 1}

One of the lowermost faunas collected (fig. 3) consists of large olenellids, the largest cephalon having a maximum transverse width of $147 \mathrm{~mm}$. Although somewhat weathered, this specimen has areas of 'Wanneria'-type ornamentation preserved, which is a strong reticulate network of distinctly raised ridges. Other characters of the cephala, however, are inconsistent with assignment to Wanneria Walcott, 1910. The material will be assigned to a new spe- 


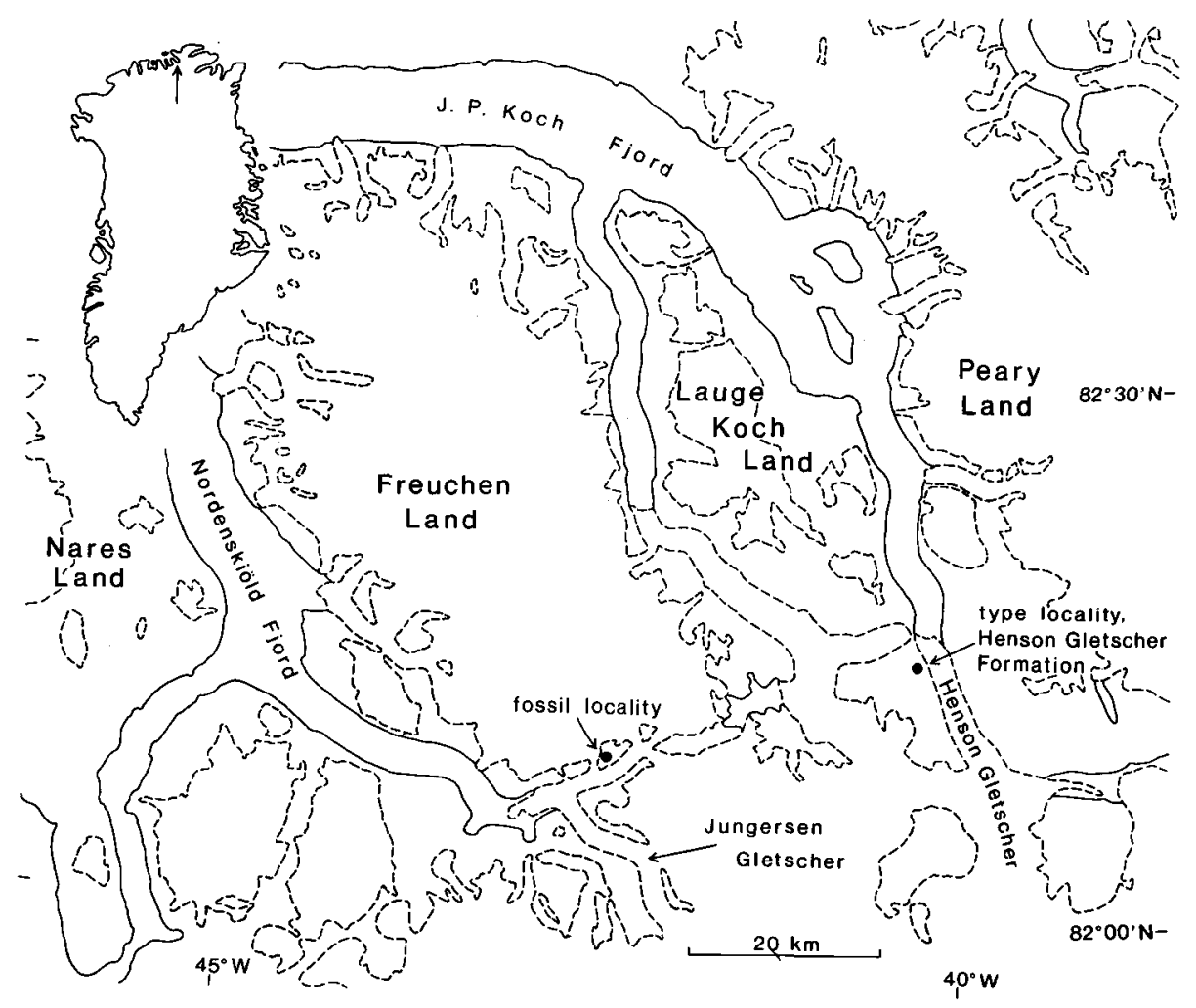

Fig. 1. Locality map.

cies of Olenellus Billings, 1861 and differs from all others in the genus in its sculpture and particularly the structure of the frontal glabellar lobe.

\section{Fauna 2}

A $5 \mathrm{~m}$ section immediately above this level was extensively collected (fig. 3). The fauna of the lower beds is dominated by species of Ogygopsis, including $O$. antiqua Palmer, 1968 and two new species of this genus. Species of Zacanthopsis Resser, 1938 and Bonnia Walcott, 1916 also occur, as well as a few specimens of Olenellus sp. The two new species of Ogygopsis are considered to be closely related forms. However, the study of large numbers of specimens collected from individual horizons has enabled consistent differences in their morphology to be recognised. Several aspects of one of the new species of Ogygopsis have already been studied, including ontogenetic development and intraspecific variation. An ontogenetic sequence consisting of late meraspides and holaspides of $O$. sp. nov. 1 has been studied. One of the most important features of the ontogeny is the relatively large size attained whilst segments are still being added to the thorax. The smallest complete holaspid specimen examined to date has a sagittal length of some $17.4 \mathrm{~mm}$, about twice the length at which trilobites attaining considerable final lengths (e.g. Paradoxides Brongniart, 1822) 


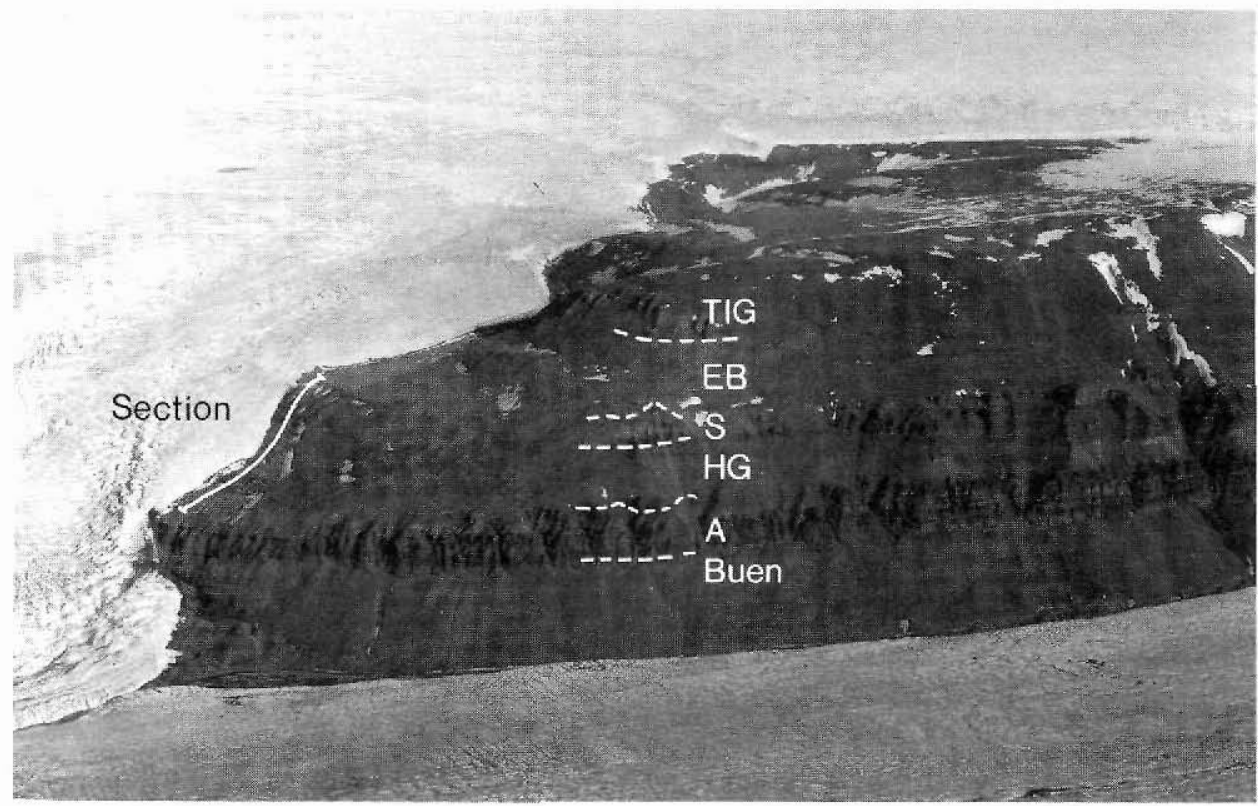

Fig. 2. Nunatak north of Jungersen Gletscher in southern Freuchen Land, viewed from the south, showing the Cambrian section from which the trilobites under discussion were collected. Buen, Buen Formation; A, Aftenstjernesø Formation; HG, Henson Gletscher Formation; S, Sydpasset Formation; EB, Ekspedition Bræ Formation; TIG, Tavsens Iskappe Group (A, HG, S, EB, Brønlund Fjord Group).

reach the holaspid condition. The longest degree seven meraspis (the final meraspid stage) has a length of $13.8 \mathrm{~mm}$. The largest specimen of $O$. sp. nov. 1 has a sagittal length of 49 $\mathrm{mm}$. A collection of over 70 articulated specimens made in 1985 will enable the ontogeny to be more fully studied and interpreted. Ogygopsis antiqua Palmer, 1968 has also been identified from higher in the section than both of the new species of Ogygopsis. O. antiqua has previously only been reported from early Cambrian strata of the Tatonduk River area of east central Alaska (Palmer, 1968, p. B50).

For $O$. antiqua a different aspect of ontogeny is being investigated. The samples contain several hundred cranidia with sagittal length less than $2 \mathrm{~mm}$. By measuring the major dimensions of every specimen, growth stages have been recognised. It is hoped that use of this method on material collected in 1985 will permit a more complete understanding of the early ontogenetic development of the cranidium.

\section{Fauna 3}

Higher in the sequence, strata dominated by limestone concretions (fig. 4) have yielded a variety of trilobites (fig. 3). Most significant perhaps is material that has been assigned to two genera of the family Oryctocephalidac Beecher, 1897 (Arthricocephalus Bergeron, 1899 and Changaspis Lee, 1963) for this family is of importance in international correlation of early Cambrian rocks. 


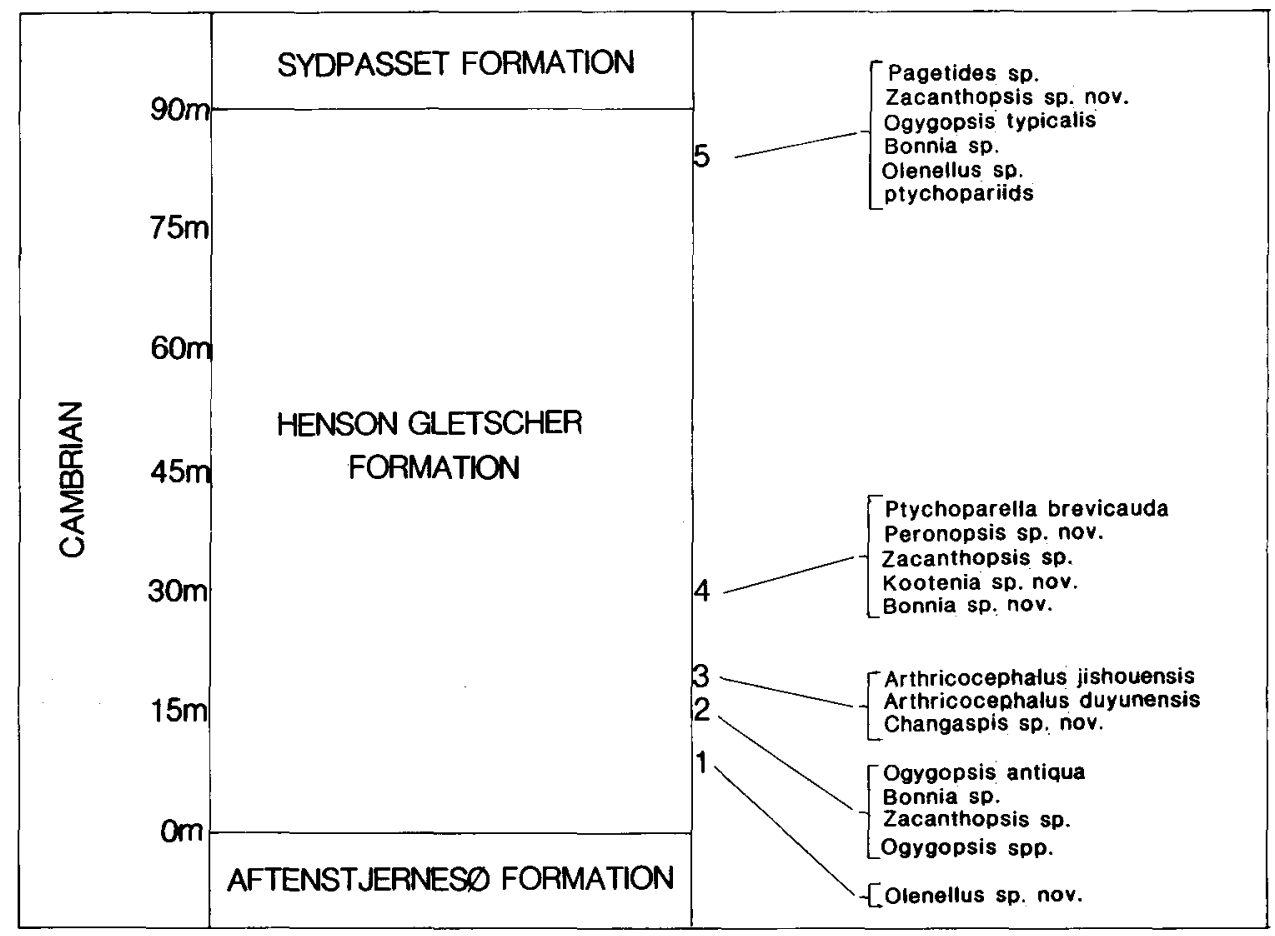

Fig. 3. Distribution of trilobite faunas within the Henson Gletscher Formation from the collection locality in southern Freuchen Land (figs $1 \& 2$ ).

Two species of the genus Arthricocephalus (A. duyunensis Chien, 1961 and A. jishouensis Zhou, 1977) and one new species of Changaspis have been identified. Both genera have previously only been reported from the Lower Cambrian of China. Both species of Arthricocephalus have been described from late Lower Cambrian strata in south-west China (Chien, 1961; Zhou, 1977), with $A$. duyunensis first being described from the Balang Shale, Duyan, Kweichow and most recently from Kunshan County, Jiangsu Province (Zhang \& Zhou, 1985). However, the significance of the records in terms of palaeogeography is difficult to assess, as palaeogeographical reconstructions for the Cambrian are speculative. The reconstruction of Morel \& Irving (1978) for the end of the Precambrian (tentatively referred to a time of about $600 \mathrm{Ma}$ ) has the Siberian Shield, Laurentia and Gondwanaland forming a single supercontinent, with Greenland and China at virtually opposite ends, and also at considerably different latitudes. There is also considerable separation between Greenland and China in the Late Cambrian to Early Ordovician reconstruction in which Baltica, Laurentia and the Siberian and Chinese shields are all isolated land masses. The Cambrian to Early Ordovician projections of Briden et al. (1974) and Smith et al. (1973) also make it unexpected that a species coexisted in North Greenland and China during the Lower Cambrian. The reconstruction of Cambrian palaeogeography by Scotese et al. (1979) places Greenland and China closer together and at similar latitudes, making it more feasible that a geographically widespread species could colonise both regions. It would, however, be ex- 


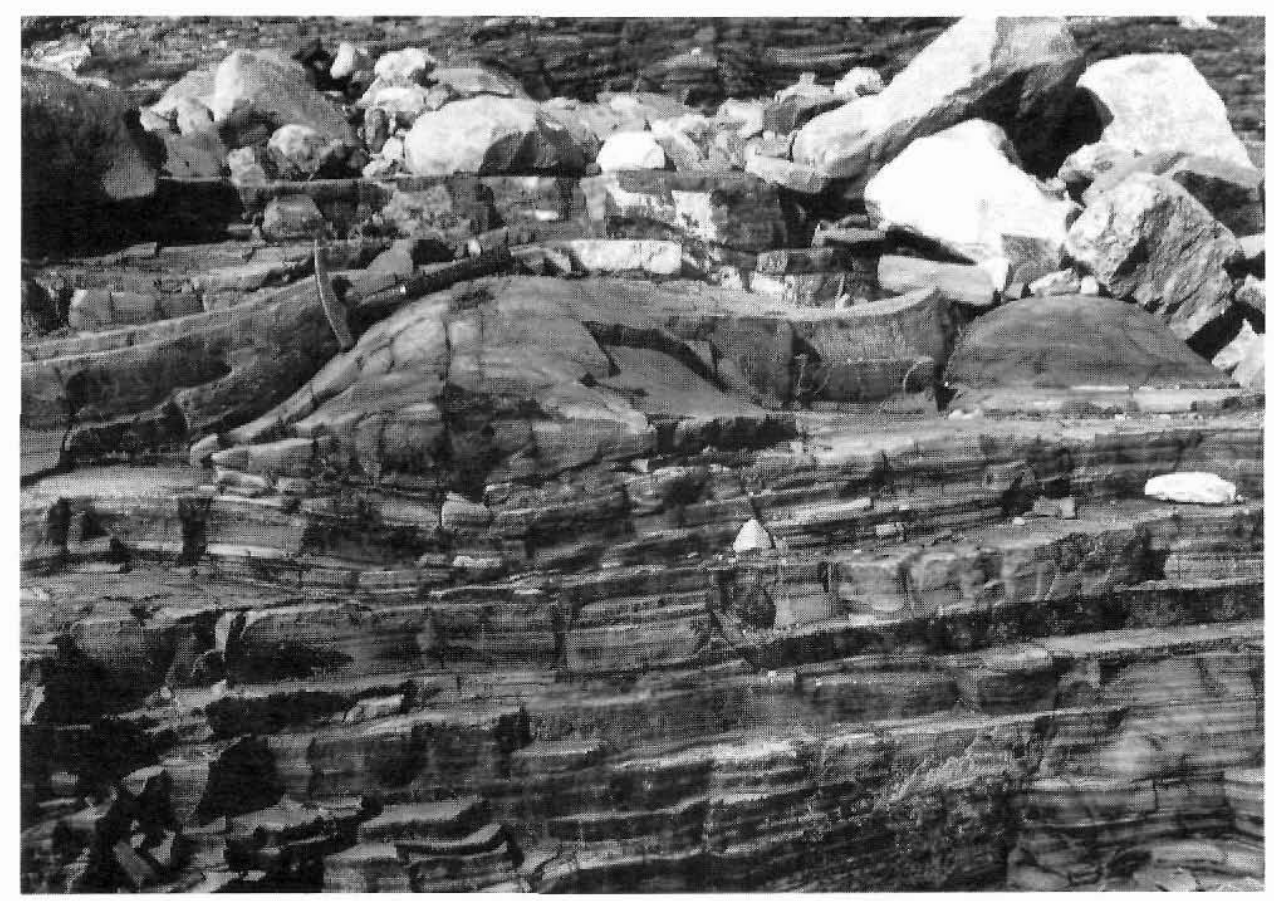

Fig. 4. Limestone concretions within the lower part of the Henson Gletscher Formation. Faunas 3 and 4 , discussed in the accompanying text, were collected from this interval.

pected from this reconstruction that the species would also occur in Siberia, but no record has been traced.

\section{Fauna 4}

Towards the top of the concretion-dominated part of the sequence an association of ptychopariid, agnostid and occasional oryctocephalid trilobites occurs (fig. 3). I have assigned specimens to a new species of Kootenia Walcott, 1889. This species is characterised by seven pairs of pygidial border spines, and prominent axial spines on the anterior four rings. As discussed by Dutro et al. (1984) both are unusual features for species of Kootenia. The pygidia have similarities to those of both $K$. jakutensis Lermontova, 1951 and $K$. anabarensis Lermontova, 1951 from Early or Middle Cambrian boundary beds of Siberia. A new species of Bonnia is distinctive by the combination of two pairs of long, slender pygidial border spines, and five or six complete axial rings. A collection of 10 pygidia of similar morphology assigned to 'genus and species undetermined 1' by Palmer (1964, p. F11) from Lower Cambrian beds of the Saline Valley Formation in Nevada has been studied, and I consider this material to be conspecific with that assigned to Bonnia sp. nov. from North Greenland. Associated with these two new species are specimens assigned to Olenoides spp. and Ogygopsis batis (Walcott, 1916). Ogygopsis batis has previously been recorded from the upper part of the Lower Cambrian of Nevada (Nelson, 1963; Palmer, 1964), from the Sekwi Formation of 
the Mackenzie Mountains, north-western Canada (Fritz, 1976), and from Siberia (Egorova et al., 1976). I have assigned an agnostid from this fauna to the geographically widespread genus Peronopsis Hawle \& Corda, 1847 and the specimens represent a new Lower Cambrian species of this genus.

The ptychopariid Ptychoparella brevicauda Poulsen, 1927 has also been identified; it is also known from Inglefield Land in North-West Greenland, some $600 \mathrm{~km}$ to the south-east, where it was described from the Middle Cambrian Cape Frederik VII Formation by Poulsen (1927). This formation was included by Troelsen (1950) within his Cape Wood Formation, a revision accepted by subsequent workers.

At present, ptychopariid classification is very confused and in the view of Palmer in Palmer \& Halley $(1979$, p. 99) “... provides the greatest problems for suprageneric classification among all the trilobites." Palmer emphasised that the problem is particularly acute in the early part of the Cambrian as most of the ptychopariid trilobites of this age are of generalised form. In addition, many forms are known only from cranidia. This affects not only suprageneric classification, but also makes generic and particularly specific classification difficult. I contend that present ptychopariid classification at the generic level for the early forms is unusable. A need exists for a new approach to these systematic problems which have been recognised by previous workers, but so far not overcome. A new approach to suprageneric groupings is discussed under fauna 5 , below.

The approach of previous classifications such as those by Lochman (1947), Rasetti (1955), Shaw (1962) and most recently Zhang et al. (1980), has been to maintain many genus level taxa that are morphologically very similar, not least because they are largely known only from their cranidia. It has been admitted that many of the taxa intergrade; Rasetti (1955, $\mathrm{p}$. 14) stated "... if lack of intermediate species were required for generic separation one would have to place most of the Ptychopariidae in a single genus." Study of the North Greenland material offers the possibility of a new approach to the question of ptychopariid relationships since large numbers of specimens of all sizes are available from individual collection localities; this allows analysis of the range of at least cranidial variation (now known to be considerable) within a single ptychopariid species.

In addition to the problem of many ptychopariid genera being only known from cranidia, comparisons between forms have not always been based on similarly-sized specimens. It has generally been the practice to allow little variation within ptychopariid taxa which has led to the formation of yet more subdivisions at all taxonomic levels. The collections to hand demonstrate the considerable variation im morphology during growth, even within the holaspid stage.

The genus Ptychoparella is a good example of the present stage of ptychopariid classification. Ptychoparella was described by C. Poulsen in 1927 with his new species $P$. brevicauda as type species. Subsequently, Resser $(1937,1938)$ and Lochman (1947) assigned Lower Cambrian specimens to several new species of Ptychoparella. Rasetti (1955, p. 7) discussed the assignment of the Lower Cambrian representatives, concluding that Ptychoparella should be confined to the Middle Cambrian type species and that no Lower Cambrian species should be referred to it. Rasetti established a new genus Eoptychoparia Rasetti, 1955 which incorporated Lower Cambrian species previously assigned to Ptychoparella.

Shaw (1962, p. 343) agreed with Rasetti on the restriction of Ptychoparella, and considered the genus to be distinguished by a combination of convergent facial sutures, an anterior border without a median inbend and small eyes situated towards the posterior. It is now 
known from the new material of Ptychoparella brevicauda that a median inbend in the anterior border is present. The other two features are not diagnostic, being features that occur in both Eoptychoparia and Ptychoparella.

Rasetti (1955, p. 13) remarked that the species he attributed to the genus Eoptychoparia 'are about average' for Lower Cambrian ptychopariids, and that the genus was difficult to characterise, for it intergraded with Antagmus Resser, 1936, Piazella Lochman, 1947 and Onchocephalus Resser, 1937. Rasetti there also commented that Eoptychoparia essentially corresponded to the concept of Ptychoparella employed by both Resser $(1937,1938)$ and Lochman (1947), which he believed neither author based on the type species, but rather on Lower Cambrian species. Further reasons were proposed by Rasetti why Eoptychoparia should be separate from Ptychoparella:

1. "The position of the eyes is more posterior in Ptychoparella." From my examination of specimens of Ptychoparella I can find no evidence to support this statement.

2. "The anterior facial sutures are slightly convergent in Eoptychoparia." The anterior facial sutures in both forms vary from slightly convergent to slightly divergent.

3. "The pygidium may have more segments in Ptychoparella." This criterion was at the time speculative. Only two pygidia have subsequently been assigned to Eoptychoparia; one is on a complete specimen assigned to $E$. wutingensis (Chang, 1964) by Zhang et al. (1980), but no detail can be seen. The second is on a complete specimen of the Middle Cambrian $E$. piochensis Palmer in Palmer \& Halley, 1979; the pygidum is not distinguishable from that of Ptychoparella brevicauda.

Rasetti (1963, p. 582) recognised a Middle Cambrian species of Eoptychoparia which he believed “... resembles in all essential features the Lower Cambrian species on which the genus is based." Palmer in Palmer \& Halley $(1979$, p. 104) also recognised a Middle Cambrian species and compared Eoptychoparia with Inglefieldia Poulsen, 1927, Luxella Rasetti, 1955, Piazella and Antagmus. Palmer made no mention of Ptychoparella despite his recognition of this Middle Cambrian form. Indeed, for $E$. piochensis, Palmer concluded that there are no consistent criteria by which it can be differentiated from the Lower Cambrian forms, in spite of Ptychoparella having been considered to be the Middle Cambrian form of the Lower Cambrian Eoptychoparia.

Poulsen (1964, p. 40) advocated that the use of Ptychoparella should be restricted to the type species until the genus was better known. Study of the specimens recently collected from the Henson Gletscher Formation now permits this re-evaluation. From a study of the type material of the type species of both Ptychoparella and Eoptychoparia, I consider that the latter is a junior synomyn of the former. There is, however, clearly a need for a more detailed revision of other species assigned to both these taxa and of other generalised ptychopariids. Zhang et al. (1980) produced the most recent classification. Although I consider that Ptychoparella and Eoptychoparia are synonyms, they were placed in different families in this classification: Ptychoparella in the Ptychopariidae Matthew, 1887 and Eoptychoparia in the Antagmidae Hupé, 1953. At present I am in agreement with Palmer in Palmer \& Halley (1979) that suprageneric groupings cannot be recognised with any certainty. Palmer (p. 99) did suggest, however, that at least one suprageneric grouping might be recognised which he termed the kochaspid trilobites, an informally defined group seemingly typical for trilobites only from the Middle Cambrian Glossopleura Zone and older North American strata. This 
approach will be applied to material from North Greenland, and is briefly mentioned under fauna 5 .

\section{Fauna 5}

At least $56 \mathrm{~m}$ of siltstones and fine-grained sandstones in which fossils were not found occur above the limestone concretion sequence. These siliciclastics are succeeded by $4 \mathrm{~m}$ of thinly-bedded dark dolomites and occasional limestones with a rich trilobite fauna (fig. 3). I have identified Pagetides sp., Bonnia sp., Olenellus sp., Ogygopsis typicalis (Resser, 1939) and a new species of Zacanthopsis. Following study of the large number of ptychopariid cranidia, two suprageneric groupings have been recognised. Both of these informal suprageneric taxa are of very generalised ptychopariids, but it is anticipated that this approach will result in a clearer understanding of ptychopariid relationships at the suprageneric level. It is their distribution in time and space that will be of critical importance in determining which genera will be placed in these higher level groupings.

Acknowledgements. The support of N.E.R.C. Research Studentship GT4/84/GS/37 is gratefully acknowledged. Niels Henriksen and John S. Peel supplied the photographs. P. D. Lane improved several earlier versions of the manuscript.

\section{References}

Briden, J. C., Drewry, G. E. \& Smith, A. G. 1974: Phanerozoic equal-area world maps. J. geol. Soc. Lond. 82, 555-574.

Chien, Y. 1961: Cambrian trilobites from Sandu and Duyun, southern Kweichow. Acta palaeontol. Sin. 9(2), 91-129.

Dutro, J. T., Palmer, A. R., Repetski, J. E. \& Brosge, W. P.: Middle Cambrian fossils from the Doonerak Anticlinorium, Central Brooks Range, Alaska. J. Paleont. 58, 1364-1371.

Egorova, L. I., Shabanov, Yu. Ya., Rozanov, A. Yu., Savitsky, V. E., Chernysheva, N. E. \& Shishkin, B. B. 1976: Elansky and Kuonamsky facies stratotypes of the lower boundary of the Middle Cambrian in Siberia. Trudy Sib. nauchno-issled. Inst. Geol. Geofiz. miner. Syr'ya. 211a, 228 pp. [In Russian.]

Fritz, W. H. 1976: Ten stratigraphic sections from the Lower Cambrian Sekwi Formation, Mackenzie Mountains, northwestern Canada. Pap. geol. Surv. Can. 76-22, 42 pp.

Ineson, J. R. \& Peel, J. S. 1980: Cambrian stratigraphy in Peary Land, eastern North Greenland. Rapp. Gronlands geol. Unders. 99, 33-42.

Ineson, J. R. \& Peel, J. S. in press: Cambrian platform - outer shelf relationships in the Nordenskiöld Fjord region, central North Greenland. Rapp. Grønlands geol. Unders.

Lermontova, E. V. 1951: Lower Cambrian trilobites and brachiopods from eastern Siberia. Vsesoyuznogo Nauchno-Issledovatel'skiy Geologicheskogo Instituta (VSEGEI), 218 pp. [In Russian.]

Lochman, C. 1947: Analysis and revision of eleven Lower Cambrian trilobite genera. J. Paleont. 21, 5971.

Morel, P. \& Irving, E. 1978: Tentative paleocontinental maps for the Early Phanerozoic and Proterozoic. J. geol. Soc. Lond. 86, 535-561.

Nelson, C. A. 1963: Stratigraphic range of Ogygopsis. J. Paleont. 37, 244-248.

Palmer, A. R. 1964: An unusual Lower Cambrian trilobite fauna from Nevada. Prof. Pap. U.S. geol. Surv. 483-F, 13 pp. 
Palmer, A. R. 1968: Cambrian trilobites of east-central Alaska. Prof. Pap. U.S. geol. Surv. 559-B, 115 pp.

Palmer, A. R. \& Halley, R. B. 1979: Physical stratigraphy and trilobite biostratigraphy of the Carrara Formation (Lower and Middle Cambrian) in the Southern Great Basin. Prof. Pap. U.S. geol. Surv. 1047, 131 pp.

Peel, J. S. 1982: The Lower Palaeozoic of Greenland. Mem Can. Soc. Petrol. Geol. 8, 309-330.

Peel, J. S. \& Wright, S. C. 1985: Cambrian platform stratigraphy in the Warming Land - Freuchen Land region, North Greenland. Rapp. Gronlands geol. Unders. 126, 17-24.

Poulsen, C. 1927: The Cambrian, Ozarkian and Canadian faunas of Northwest Greenland. Meddr Grønland 70(6), 233-343.

Poulsen, V. 1964: Contribution to the Lower and Middle Cambrian palaeontology and stratigraphy of Northwest Greenland. Meddr Grønland 164(6), $105 \mathrm{pp}$.

Rasetti, F. 1955: Lower Cambrian ptychopariid trilobites from the conglomerates of Quebec. Smithson. misc. Coll. 128(7), 35 pp.

Rasetti, F. 1963: Middle Cambrian ptychopariid trilobites from the conglomerates of Quebec. J. Paleont. 11, 575-594.

Resser, C. E. 1937: Elkanah Billings' Lower Cambrian trilobites and associated species. J. Paleont. 11, 43-54.

Resser, C. E. 1938: Cambrian system (restricted) of the southern Appalachians. Spec. Pap. geol. Soc. Am. 15, 130 pp.

Robison, R. A. 1982: Some Middle Cambrian agnostid trilobites from western North America. J. Paleont. 56, 132-160.

Scotese, C. R., Bambach, R. K., Barton, C., van der Voo, R. \& Ziegler, A. M. 1979: Paleozoic base maps. J. geol. Soc. Lond. 87, 217-277.

Shaw, A. B. 1962: Paleontology of northwestern Vermont IX. Fauna of the Monkton Quartzite. J. Paleont. 36, 322-345.

Smith, A. G., Briden, J. C. \& Drewry, G. E. 1973: Phanerozoic world maps. Spec. Pap. Palaeontology 12, 1-43.

Troelsen, J. C. 1950: Contributions to the geology of Northwest Greenland, Ellesmere Island and Axel Heiberg Island. Meddr Grønland 149(7), $86 \mathrm{pp}$.

Zhang, Q. \& Zhou, Z. 1985: Early Cambrian trilobite fauna of Kunshan, Jiangsu. Acta palaeont. Sin. 24, 259-266.

Zhang, W., Lu, Y., Zhu, Z., Qian, Y., Lin, H., Zhou, Z., Zhang, S. \& Yuan, J. 1980: Cambrian trilobite faunas of southwestern China. Palaeontol. Sin. new ser. B, 16, 497 pp.

Zhou, Z. 1977: In Wang, X. \& Jin, Y. (edit.) Palaeontological handbook of central and southern China. Part 1, Early Palaeozoic, 470 pp. Peking: Sci. Press. [In Chinese.] 